\title{
FIELD STUDY FOR SEASONAL EFFECTON PRODUCTIVE PERFORMANCE OF BROILER BREEDER CHICKENS
}

\author{
A.I. El-Faham; S.A. Ibrahim; S.A. El-Safty; M.S. Hassanien; Nematallah, G.M. Ali and \\ G.N. Rayan
}

Poult. Prod. Dept. Fac. of Agric., Ain Shams Univ., Cairo, Egypt.

\section{SUMMARY}

$\mathrm{T}$ This study was conducted to evaluate the effects of season (summer versus winter) at different ages on productive performance (body weight, feed consumption, mortality \%, egg weight and egg production \%) of Hubbard classic broiler breeder's females during egg production period (25-45 wks). The birds were fed according to the program feeding of producer company. The results revealed that there were significant differences in productive performance betweentwo seasons at different egg production periods. Body weight, feed consumption, egg weight and egg production \% were significantly higher in winter than summer season. However, mortality rate was significantly lower in winter compared with summer season. Moreover, productive performance was significantly affected by season, breeder age and their interaction. It could be concluded that, there were significant differences in productive performance of broiler breeder chickens (Hubbard classic) under the two seasons (summer versus winter) at different egg production periods (25- $45 \mathrm{wks})$.

Keywords: broiler breeder, seasons, productive performance.

\section{INTRODUCTION}

The development of broiler breeder chickens sector in Egypt suffers many constraints hindering its overall growth, and laying production. Environmental stress include biotic factors (such as nutrition, competition and various forms of infections diseases) and abiotic factors (such as climate, temperature and chemical components), which can act independently, but often act synergistically (Bijlsma and Loeschcke, 2005). Climate changes, seasonal variation, heat stress and/or increasing extremities in weather patterns have been the major non-genetic factors affectingbroiler breeder production (Obidi et al., 2008; Oguntunji and Alali, 2010 and Olawumi, 2013). Theideal temperature for laying hens is about $20^{\circ} \mathrm{c}$ (North and Bell, 1990). However, in Egypt, during the summer season environmental temperature are often between $35-40^{\circ} \mathrm{c}$ and humidity reach $75 \%$ (Abou-Shehema et al., 2016). Heat stress in laying hens reduces live weight gain, feed intake, feed efficiency, production and quality of eggs and increases mortality (Daghir, 2008). Yakubu et al., 2007 and Barbosa et al., 2012) showed that, body weight henhoused egg production and egg weight were higher in the wet season compared with the hot - dry season. Whereas, high mortality rate in the hot-dry season has been documented (Bannor and Ogunsan, 1987) and the better performance in the wet season could be as a result of high feed consumption and utilization which were characteristicof cooler environmental conditions.

Therefore, in general the objective of this field study was to investigate the effect of seasons on productive performance (body weight, feed consumption, mortality rate, eggweight and egg production) of Hubbard classic broiler breeder chickens.

\section{MATERIALS AND METHODS}

The present study was carried out at a private local broiler breeder farm in Alexandria desert road, that belonging to El-Behara government, Egypt. The aim of this study was to investigate the effects of different seasons (winter vs. summer) on the productive performance of Hubbard classic broiler breeder chickens. Two parent flocks were used in this study, the first one (7551 chickens +882 cocks) starting the production period during winter season (October to January), while the second flock (7052 chickens + 1004 cocks) starting the production period during summer season (May to October). Standard feeders, waterers, lighting and densities were used throughout the experiment period (25-45 wks of age) 


\section{El-Faham et al.}

according to the guideline of Hubbard breeder's company. Productive performance was evaluated by measuring body weight (g), body weight gain (g), feed consumption g/day, Mortality \%, egg weight (g) and egg production \% during certain period ( $25-45$ wks of age).

\section{Statistical Analysis:}

Data were analyzed using two-way analysis of variance with season (winter vs. summer), age and their interaction using the General Linear Model (GLM) procedure of SAS (2002) as following model;

$\mathrm{Y}_{\mathrm{ijk}}=$ Trait measured

$$
\mathrm{Y}_{\mathrm{ijk}}=\mathrm{M}+\mathrm{A}_{\mathrm{i}}+\mathrm{H}_{\mathrm{j}}+(\mathrm{AH})_{\mathrm{ij}}+\mathrm{e}_{\mathrm{ijk}}
$$

$\mathrm{M}=$ Overall mean

$\mathrm{A}_{\mathrm{i}}=$ Age effect

$\mathrm{H}_{\mathrm{j}}=$ Season effect $(\mathrm{i}=1,2)$.

$(\mathrm{AH})_{\mathrm{ij}}=$ Interaction between season and age.

Eijk = Experimental error

When significant differences among means were found, means were separated using Duncan's multiple range tests (Duncan, 1955).

\section{RESULTS AND DISCUSSION}

\section{Effect of season and broiler breeder chickens age on productive performance:}

The effect of season (S) broiler breeder chickens age (A) and ( $\mathrm{S} \times \mathrm{A}$ ) interaction on productive performance ofbroiler breeder chickens (Hubbard classic) can be shown as follows:

\section{Live body weight:}

Data in Table (1) indicate that there were significantly effects on chickens body weight between different seasons(summer and winter) and the corresponding values were $3289.3 \mathrm{~g}$ and $3513.33 \mathrm{~g}$, respectively. Moreover, body weight was significantly affected by breeder age whereas, body weight of females increased with advancing of breeder age. In the same order, body weight was significantly affected by interaction between season and breeder age. Similar observations were reported by other investigators, Al-Rawi and Abou-Ashour (1983), who reported that body weight declined withincrease in temperature and was also affected by environment - associated stress. Also, the better performance in body weight in the wet season could be as a result of high feed consumption and utilization which were characteristic of cooler environement conditions (Yakubu et al., 2007 and Daghir, 2008).

\section{Feed consumption and mortality percentages:}

Data in Table (2) show the relationship between season and feed consumption and mortality percentages at different ages of Hubbard classic broiler breeders hens. The obtained data showed that there were significant differences in feed consumption and mortality percentages among season during the studied period (25- $45 \mathrm{wks}$ ). Feed consumption of breeder during egg production period significantly was $(157.81 \mathrm{~g} /$ day $)$ in winter time as compared to $(148.2 \mathrm{~g} /$ day $)$ in summer time.

Concerning age of breeder chickens, the highest value of Feed consumption (160.4 and $164.5 \mathrm{~g} /$ day) was recorded during the periods of (31- 35) and (36-40) wks of age, while the lowest value (140.64 g) was recorded during the period of $(25-30)$ wks of age. The lower feed consumption during summer season may probably be one of the physiological responses employed by the bird to reduce increased body heat load associated with feed intake most especially when environmental temperature is elevated (Simon, 2003). These results are in agreement with those obtained by Al-Rawi and AbouAshour (1983), Olawumi (2007) and Awad et al. (2016), they concluded that feed intake declined with increase in temperature and also affected by environmental - associated stress. In addition, feed intake was higher in the wet season compared with the hot-dry season and high temperature and humidity influence the rate and extent of growth in birds. Data in Table (2) indicate that mortality rate (\%) increased in summer time compared with those in winter time. The corresponding figures were $(0.76$ versus $0.15 \%)$, with significant differences.

In the same order, there were significant differences for mortality $\%$ of breeder chickens with age. The highest value was detected during $(31-35)$ weeks of age. On the other hand, the lowest value was recorded during (25-30) weeks of age. The corresponding figures were 0.79 versus $0.27 \%$ with significant differences between the two period ages. In addition, mortality (\%) was significant affected by interaction between season and breeder age. 
These results were agreed with Bannor and Ogunsan (1987) and Yakubu et al. (2007), they reported that according to the effect of season, the mean of mortality in the hot-dry and wet seasons was significantly affected and the highest mortality rate during the hottest periods of the year could be as a result of heat stress which lessened the immune response of the birds to weather fluctuations, there by predisposing them to heat stroke or pathogenic organisms and eventual death.

\section{Egg weight and egg production \%:}

Productive performance of breeder chickens as affected by season and age during experimental period (20 wks) was illustrated in Table (3) and Figure (1).It was worth to not that egg weight was significant affected by season or breeder age, while no significant difference according to the interaction (season $\mathrm{x}$ age) and the higher value of egg weight was (64.33 g) during winter time and was (58.25 g) during summer time. Besides, the differences between the two seasons were significant. On the other hand, it could be observed that the lowest value of egg weight (55.93 g) during production period (25-30 wks) and egg weight increased gradually as breeder age progressed.

Similar trend was noticed by Rizzi and Chiericato (2005), Yakubu et al. (2007) and Ojedapo et al. (2008). They found that the egg weight increased with the hens age and according to the effect of season, egg weight was significant higher in the wet season compared with the hot-dry season.

Egg production $\%$ showed the same trend since there was significant difference in egg production percentage of breeders according to the season, which it was $(41 \%)$ in summer and $(57 \%)$ in winter and breeder age, the highest percentage of production was recorded during (36-40 wks) of age (61.3\%), while the lowest percentage was recorded during (25-30 wks), $22 \%$ which is at the beginning of egg production period. This result supports the findingof Ma et al. (2014), who reported that egg production decreased through summer season may be due to heat stress which may cause a hormonal distortion equilibrium associated with ovarian activities and reduce feed intake as well as decrease antioxidant capacity which will simultaneously prevent birds from intake of necessary nutrients needed for body maintenance and egg production. On the other hand, Al-Daraji and Tahir (2013) showed that increase egg production and egg weight may be due to improving the formations and secretion of albumin layers by stimulating lipoprotein precursors synthesis in the liver and then deposited into oviduct.

These findings agreed with the results of Olawumi and Ogunlade (2010), Barbosa et al. (2012), Melesseet al. (2013), Olawumi (2013 and 2015) and Abdel-Azeem et al. (2015), they reported that henhoused egg production was higher in the wet season compared with the hot-dry season.

\section{REFERENCES}

Abdel-Azeem, A.F.; T.A. Shamma and Y.O. Omara (2015). Seasonal variation and performance evaluation of broiler breeder chickens reared in enclosed houses. Egypt. Poult. Sci. (IV): 833-856.

Abou-Shehema, B.M.; Rawia, S. Hamed; M.M. Khalifah and A.A. Abdalla (2016). Effect of silymarin supplementation on the performance of developed chickens under summer conditions 2-during laying p[eriod. Egypt. Poult. Sci. Vol. (36): 1233-1249.

Al-Daraji, H.J. and A.O. Tahir (2013). Effect of dietary supplementation with L-carnitine on productive performance of local duck. Inter. J. of Agric. Sci., 3: 101-110.

Al-Rawi, B.A. and A.M. Abou-Ashour, (1983). Performance of laying hens under different housing and environmental conditions. World Rev. Anim. Product, 19: 54-60.

Awad, A.L.; H.N. Fahim and M.M. Beshara (2016). Effect of season and dietary L-carnitine supplementation on productive and reproductive performance of local duck breeds. Egypt. Poult. Sci. (I): $29-51$.

Bannor, T.T. and E.A. Ogunsan (1987).The effects of environmental temperatures on intensive poultry production on Sokoto State of Nigeria. Bull. Anim. Health Product. 35: 39-45.

Barbosa, V. M.; N.C. Baião; P.M.M. Mendes; J.S.R. Rocha; M.A. Pompeu; L. J.C. Lara; N.R.S. Martins; D.L. Nelson; D.J.A. Miranda; C. E. Cunha; Cardoso, D.M.; Cardeal and P.C. Avaliação (2012). Da qualidade da casca dos ovosprovenientes de matrizespesadas com diferentesidades. ArquivoBrasileiro de MedicinaVeterináriaeZootecnia, Belo Horizonte, v.64, n.4, p.1036-1044.

Bijlsma, R. and V. Loeschcko (2005). Environmental stress, adaptation and evolution: An overview. J. Evol. Biol., 18: 744-749.

Daghir, N.J. (2008). Poultry production in hot climates, $2^{\text {nd }}$ ed. CAB International, Wallinford, Oxfordshire. P: 387. 


\section{El-Faham et al.}

Duncan, D.M, (1955). Multiple range and multiple F-tests. Biometrics 11:1-42.

Ma, X.; Y.Lin; H. Zhang; W. Chen; S. Wang; D. Ruan and Z. Jiang (2014). Heat stress impairs the nutritional metabolism and reduces the productivity of egg-laying ducks. Anim. Rep. Sci., 145: 182190.

Melesse, A.; S. Maak; H. Pingel and G.V. Lengerchen (2013). Assessing the thermo-tolerance potentials of five commercial layer chicken genotypes under long-term heat stress environment as measured by their performance traits. J. Anim. Prod. Adv. 3(8): 254-264.

North, M.O. and D.D. Bell (1981).Breeder Management. In: "Commercial Chicken Production Manual". 4th Ed., Van Nostrand Reinhold. New York, USA.

Obidi, J.A.; B.I. Onyeanusi; P.I. Rekwot; J.O. Ayo and T. Dzenda (2008). Seasonal variations in seminal characteristics of shika brown breeder cocks. Inte. J. Poult. Sci., 7(12): 1219-1223.

Oguntunji, O.M. and A.O. Alali (2010). Influence of high environmental temperature on egg production and shell quality a review. World's Poult. Sci. J. 66: 739-774.

Ojedapo, L.O.;J.O. Akinokun;T.A. Adedeji;T.B. Olayeni;A.O. Ige and S. R. Amao (2008). Evaluation of growth traits and short-term laying performance of three different strains of chicken in the derived savanna zone of Nigeria. International Journal of Poultry Science 7(1): 92-96.

Olawumi, (2013). Effect of Month of Production on Reproductive Traits of Barred Plymouth Rock Parent Stock in the Humid Tropics. Animal Breeding and Genetics Unit, Department of Animal Production and Health Sciences, Ekiti State University, P. M. B. 5363, Ado-Ekiti, Nigeria. Vol 1, No 1.

Olawumi, S.O. (2007). Genotype x season interaction effects on reproductive performance of two breeds of layer breeders in humid zone in Nigeria. Appl. Tropical Agric. 12(2): 78-82.

Olawumi, S.O. (2015). The effect of seasonal variability on fertility and mortality rates of two strains of breeder cocks in the humid trpoics. J. Anim. and Vet. Sci., 2: 43-46.

Olawumi, S.O., and J.T. Ogunlade (2010). Phenotypic Correlations between Reproductive Traits in Layer Breeders and Weather Variables in Humid Zone of Nigeria. Int. J. Anim. Sci. 2(1): 113-120.

Rizzi C. andG.M. Chiericato (2005).Organic farming production. Effect of age on the productive yield and egg quality of hens of two commercial hybrid lines and Two local breeds. Italian Journal of Animal Science. 4:160-162.

SAS institute (2002). SAS/STAT Users Guide statistics Ver.9.1; SAS institute Inc. Cary, NC.

Simon, M.S. (2003). Reducing heat stress problem. World poult. Sci. 19:16-17.

Yakubu, A.; A. Salako and A. Ige (2007). Effects of genotype and housing system on the laying performance of chickens in different seasons in the Semi-Humid Tropics. Int. J. Poult. Sci. 6: 434439. 
Egyptian J. Nutrition and Feeds (2017)

دراسة حقلية لتأثير الموسم على الأداء الإنتاجى لأمهات دجاج التسمين

أحمد إبراهيم الفحام، سيد عبد الرحمن إبراهيم، صلاح الدين عبد الرحمن الصفتى، محمد سامى حسنين، نعمة الله جمال الدين وجمال ناجى ريان النان

قسم إنتاج اللواجن- كلية الزراعة- جامعة عين شعس- مصر

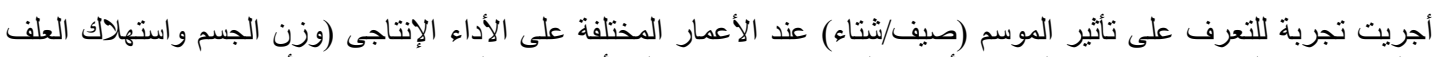

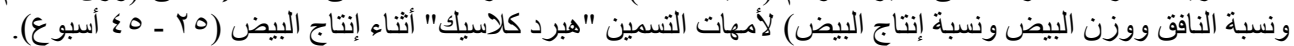
غذيت الطيور تبعأ للبرنامج المقدم من الثركة المنتجة للألأمهات.

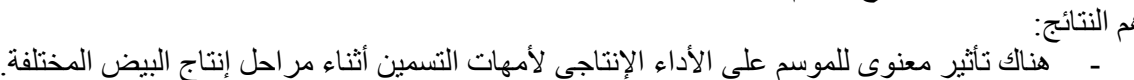

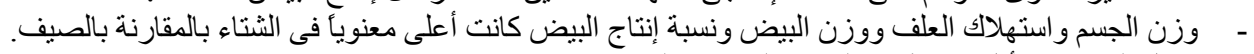

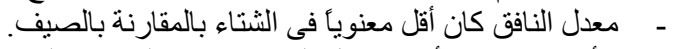

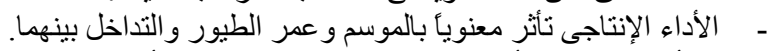

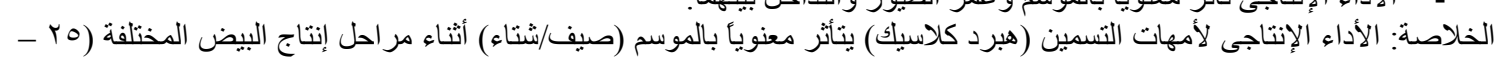
( أسبوعة). الأداء. 
Table (1): Effect of season at different ages on body weight (g) of Hubbard classic broiler breeders females during egg production period (from 25 to 45 weeks) (Means $\pm \mathrm{SE}$ ).

\begin{tabular}{|c|c|c|c|c|c|c|c|}
\hline \multirow{2}{*}{ Trait } & \multirow{2}{*}{$\begin{array}{c}\text { Age, wk } \\
\text { (A) }\end{array}$} & \multicolumn{2}{|c|}{ Season $(\mathrm{S})$} & \multirow{2}{*}{ Overall } & \multicolumn{3}{|c|}{ Probability } \\
\hline & & Summer & Winter & & $S$ & $\mathrm{~A}$ & $\mathrm{~S} * \mathrm{~A}$ \\
\hline \multirow[t]{7}{*}{ Body weight, g } & & & & & 0.05 & 0.0001 & 0.0001 \\
\hline & & 3245.00 & 3108.67 & & & & \\
\hline & $25-30$ & \pm 148.00 & \pm 82.53 & $3142.75^{\mathrm{c}}$ & & & \\
\hline & $31-35$ & $\begin{array}{l}3600.00 \\
\pm 109.01\end{array}$ & $\begin{array}{c}3498.40 \\
\pm 33.26\end{array}$ & $3515.33^{\mathrm{ab}}$ & & & \\
\hline & $36-40$ & $\begin{array}{l}3602.50 \\
\pm 106.50\end{array}$ & $\begin{array}{c}3696.40 \\
\pm 26.50\end{array}$ & $3669.57^{\mathrm{a}}$ & & & \\
\hline & $41-45$ & $\begin{array}{l}3119.60 \\
\pm 132.33\end{array}$ & $\begin{array}{c}3830.80 \\
\pm 27.40\end{array}$ & $3475.20^{\mathrm{b}}$ & & & \\
\hline & Overall & $3289.30^{b}$ & $3513.33^{\mathrm{a}}$ & & & & \\
\hline
\end{tabular}

a,band C Means within the same main effects with different letters are significantly differed, NS= Non-significant

Table (2): Effect of season at different ages on feed consumption and mortality percentage of Hubbard classic broiler breeder's females during egg production period (from 25 to 45 weeks) (Means $\pm \mathrm{SE})$.

\begin{tabular}{|c|c|c|c|c|c|c|c|}
\hline \multirow{2}{*}{ Trait } & \multirow{2}{*}{$\begin{array}{l}\text { Age, } \\
\text { wk } \\
\text { (A) }\end{array}$} & \multicolumn{2}{|c|}{ Season $(\mathrm{S})$} & \multirow{2}{*}{ Overall } & \multicolumn{3}{|c|}{ Probability } \\
\hline & & Summer & Winter & & $\mathrm{S}$ & A & $\mathrm{S} * \mathrm{~A}$ \\
\hline feed consumption, g/day & $\begin{array}{c}25-30 \\
31-35 \\
36-40 \\
41-45 \\
\text { Overall } \\
\end{array}$ & $\begin{array}{c}155.80 \pm 4.62 \\
164.00 \pm 1.00 \\
154.00 \pm 2.92 \\
119.00 \pm 8.72 \\
148.20^{\mathrm{b}}\end{array}$ & $\begin{array}{c}128.00 \pm 2.16 \\
156.80 \pm 3.10 \\
175.00 \pm 2.85 \\
177.40 \pm 0.24 \\
157.81^{\mathrm{a}}\end{array}$ & $\begin{array}{r}140.64^{\mathrm{b}} \\
160.40^{\mathrm{a}} \\
164.50^{\mathrm{a}} \\
148.20^{\mathrm{b}}\end{array}$ & 0.0001 & 0.0001 & 0.0001 \\
\hline Mortality percentage $(\%)$ & $\begin{array}{c}25-30 \\
31-35 \\
36-40 \\
41-45 \\
\text { verall }\end{array}$ & $\begin{array}{c}0.50 \pm 0.10 \\
1.45 \pm 0.22 \\
0.55 \pm 0.08 \\
0.52 \pm 0.09 \\
0.76^{\mathrm{a}}\end{array}$ & $\begin{array}{c}0.07 \pm 0.02 \\
0.13 \pm 0.02 \\
0.25 \pm 0.06 \\
0.24 \pm 0.01 \\
0.15^{\mathrm{b}}\end{array}$ & $\begin{array}{l}0.27^{\mathrm{b}} \\
0.79^{\mathrm{a}} \\
0.40^{\mathrm{b}} \\
0.48^{\mathrm{b}}\end{array}$ & 0.0001 & 0.0001 & 0.0001 \\
\hline
\end{tabular}


Table (3): Effect of season at different ages on egg weight (g) of Hubbard classic broiler breeders females during egg production period (from 25 to 45 weeks) (Means \pm SE).

\begin{tabular}{|c|c|c|c|c|c|c|c|}
\hline \multirow{2}{*}{ Trait } & \multirow{2}{*}{$\begin{array}{l}\text { Age, wk } \\
\text { (A) }\end{array}$} & \multicolumn{2}{|c|}{ Season $(\mathrm{S})$} & \multirow{2}{*}{ Overall } & \multicolumn{3}{|c|}{ Probability } \\
\hline & & Summer & Winter & & $\mathrm{S}$ & $\mathrm{A}$ & $\mathrm{S} * \mathrm{~A}$ \\
\hline Egg weight, g & & & & & 0.0001 & 0.0001 & NS \\
\hline & $25-30$ & $51.00 \pm 0.01$ & $57.57 \pm 1.09$ & $55.93^{\mathrm{b}}$ & & & \\
\hline & $31-35$ & $58.00 \pm 0.02$ & $62.50 \pm 0.68$ & $61.75^{\mathrm{c}}$ & & & \\
\hline & $36-40$ & $60.00 \pm 0.02$ & $66.28 \pm 0.63$ & $65.23^{\mathrm{b}}$ & & & \\
\hline & 41-45 & $64.00 \pm 0.01$ & $68.28 \pm 0.31$ & $67.57^{\mathrm{a}}$ & & & \\
\hline & Overall & $58.25^{\mathrm{b}}$ & $64.33^{\mathrm{a}}$ & & & & \\
\hline
\end{tabular}

$a, b, C$ and d Means within the same main effects with different letters are significantly differed, NS= Non-significant .

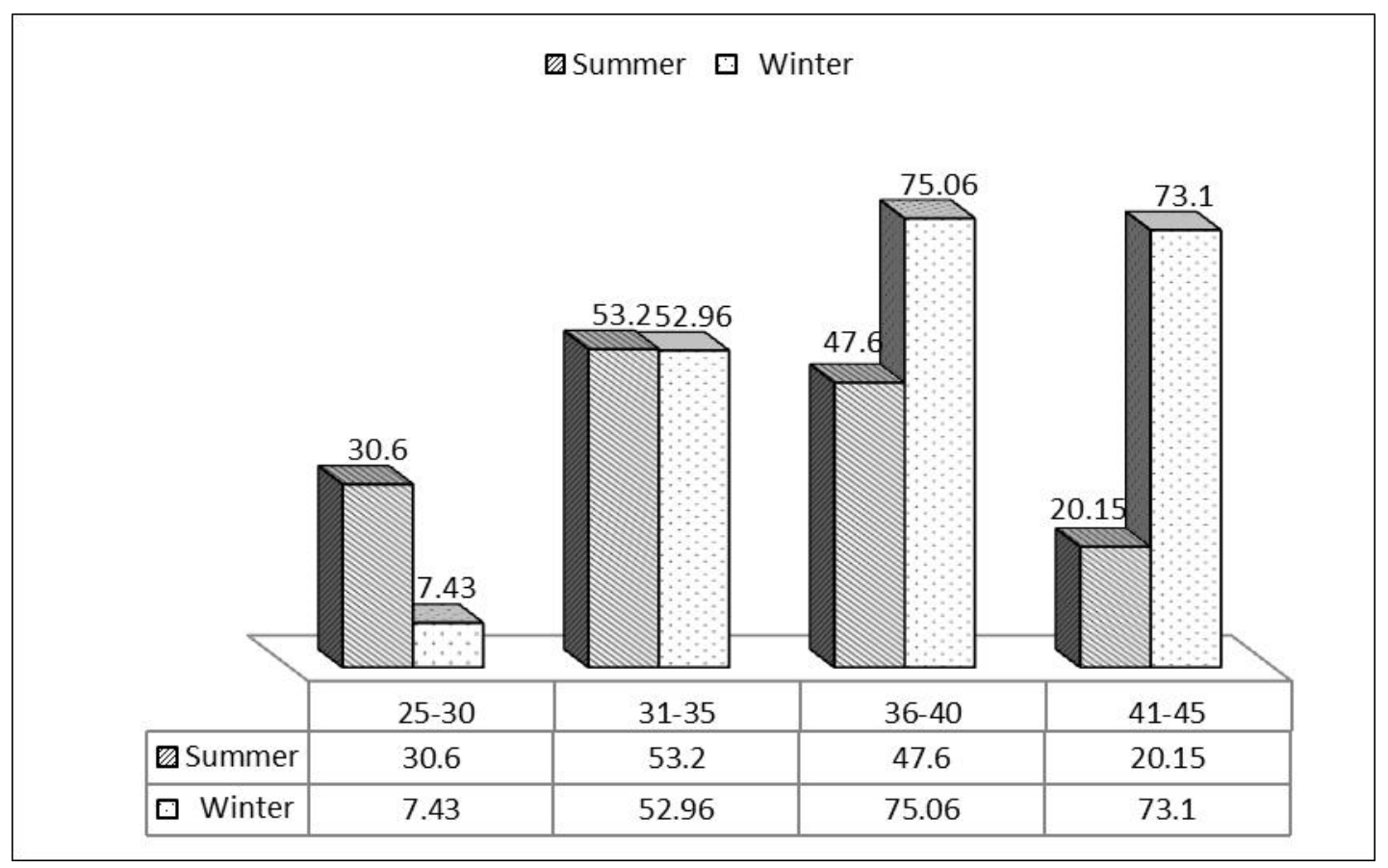

Fig. (1): Effect of season on egg production(\%) of Hubbard classic broiler breeders females. 